\title{
Garnet-An Essential Industrial Mineral and January's Birthstone
}

arnet is one of the most
common minerals in the
world. Occurring in almost any
color, it is most widely known
for its beauty as a gem stone.
Because of its hardness and
other properties, garnet is also an
essential industrial mineral used
in abrasive products, non-slip
surfaces, and filtration. To help
manage our Nation's resources of
such essential minerals, the U.S.
Geological Survey (USGS) pro-
vides crucial data and scientific
information to industry, policy-
makers, and the public.

\section{Garnet as a Gem Stone}

Garnet is familiar to many people as January's birthstone and as the New York State gem stone. It has been used as a gem stone since prehistoric times. Most recognizable in a deep shade of red, garnet occurs in the greatest variety of color of any mineral, except for blue. Some types of garnet even change color when exposed to artificial light.

Unlike many other gem stones, garnet is almost never treated using heat, chemicals, or other methods to enhance appearance and value. The value of gem-stone garnets involves a complex combination of factors, including color, clarity, scarcity, durability, type of cut, and fashion. Larger garnets are popular both as gems and as collectable mineral specimens. Star garnets, found in Idaho, India, and Madagascar, contain inclusions of the fibrous mineral rutile that reflect light in two, four, or six rays when the stones are cut and polished. Star garnets with six rays are the rarest, and for about every 500 four-ray garnets only 1 six-ray garnet is found.

\section{Garnet as an Industrial Mineral}

The first industrial use of garnet appears to have been in coated sandpaper manufactured in the United States by Henry Hudson Barton

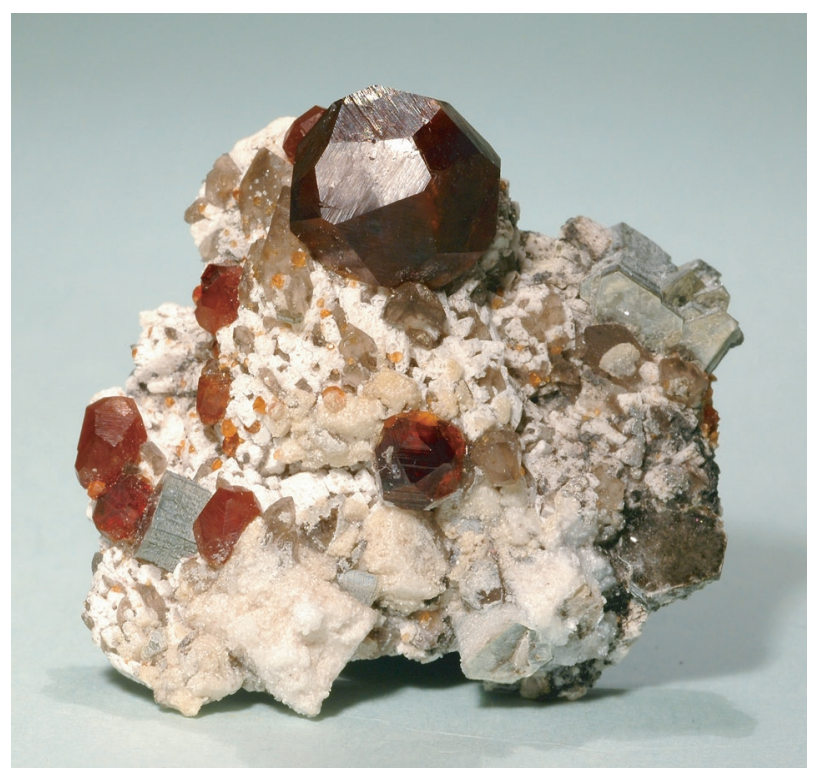

Photograph of a mineral specimen containing large crystals of the garnet mineral spessartine (red), showing the distinctive "euhedral isometric" crystal form of garnet. Used since ancient times for jewelry, the first industrial use of garnet was probably in coated sandpaper manufactured in the United States by Henry Hudson Barton in 1878. The United States currently consumes about 16 percent of the global production of industrial garnet. (Copyrighted photo by Stan Celestian/ courtesy of Glendale Community College). in 1878. Garnet is an important industrial mineral because it is relatively hard, rating 6 to about 8 on the "Mohs scale of hardness," where diamond is the hardest at 10 . Consequently, garnet is an excellent abrasive for applications such as sand- or air-blasting, water-jet cutting, and sandpaper. Garnet is now used for some blast-cleaning applications that previously used common sand. Common sand contains crystalline silica $\left(\mathrm{SiO}_{2}\right)$ that in the form of dust produced during blasting can cause lung damage if inhaled.

There are many additional industrial applications of garnet, including condition-

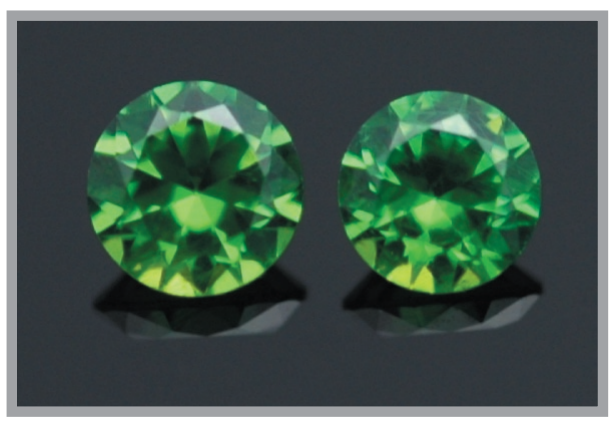

These cut and polished gem stones are a rare, green variety of andradite garnet, also known as "demantoid" garnet. Cut garnets are prized for their beauty and are also commercially valuable for use in jewelry. (Image courtesy of Peter Grumitt.) ing aluminum and other soft metals for use in aircraft and ships; deburring welds and grinding and polishing optical lenses; producing high-quality, scratch-free semiconductor materials; finishing hard rubber, plastic, and wood products; and making nonskid paints and coatings. The U.S. petroleum industry is one of the leading garnet-consuming industries, using garnet for cleaning drill pipes and well casings. Garnet is also chemically inert and recyclable, making it an ideal filtration medium.

Garnet can also be used in mining exploration as an indicator to help locate diamond deposits. Diamonds only form at great pressure and temperature and are associated with kimberlite, an intrusive igneous rock that comes from deep within the Earth. As the molten rock (magma) that cools to form a kimberlite rises toward the Earth's surface, it incorporates fragments of rocks and minerals, including garnets with distinct color and composition that form under the same conditions as diamonds. If these distinct types of garnet are found in sediments, they may indicate the presence of nearby diamondbearing kimberlites.

\section{How do Garnets Form?}

Garnet crystals form in rocks of appropriate chemical composition that have been 


\section{The Industrial Uses of Garnet}

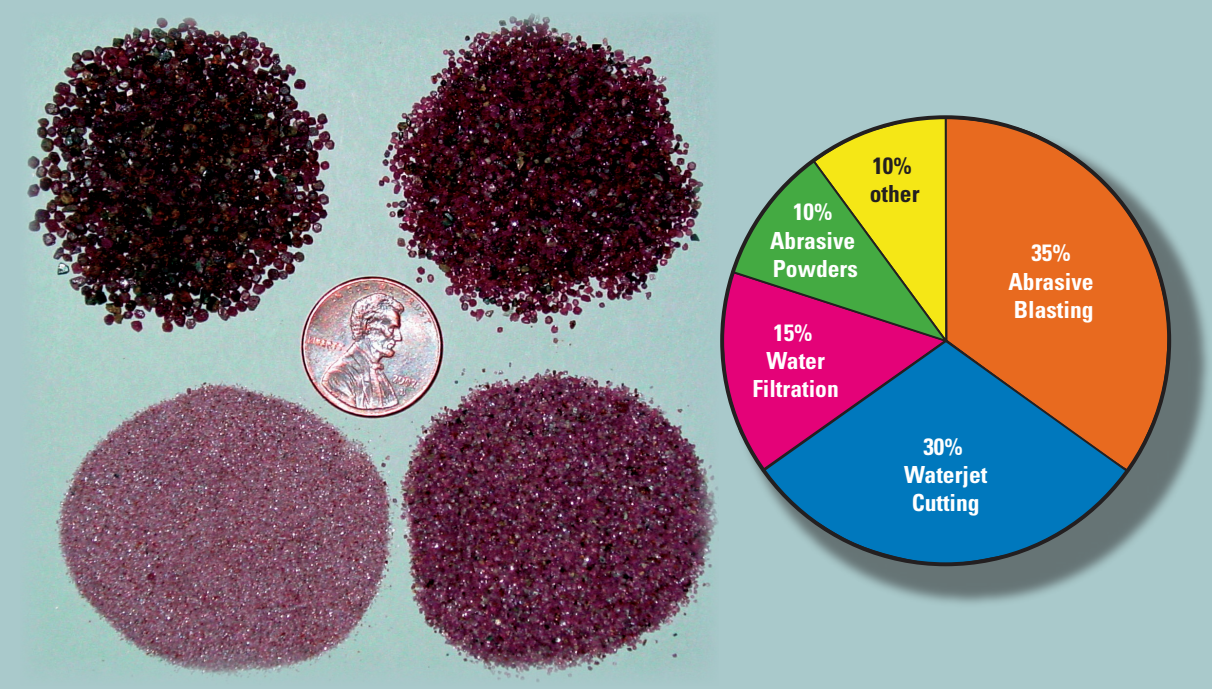

This photo shows garnets of various grain sizes. Garnets are hard, chemically inert, and recyclable, making them ideal for industrial uses (see pie diagram). Garnets similar to those shown here are used in water-jet cutting, air-blasting, and filtration applications. modified by heat and pressure deep within the Earth's crust. These are "metamorphic" rocks, such as gneiss, amphibolite, and schist. Less frequently, garnets form in "calcareous" rocks that have been heated by nearby intrusions of magma.

Garnets can be recovered using either surface or underground mining methods. Most garnets are found in and recovered from alluvium (unconsolidated or poorly consolidated combinations of clay, silt, sand, and gravel) derived from metamorphic rocks that have undergone weathering and erosion. Subsequent stream action moves and deposits the garnets, resulting in local concentrations of garnet due to its high specific gravity (its mass relative to an equal volume of water). During the recovery process the specific gravity and magnetic properties of garnet are used to separate it from other material.

\section{Are all Garnets the Same?}

Although all garnets possess similar physical properties, including crystal structure, hardness, and specific gravity, there are actually several different types of the mineral. The six most common members of the garnet family are almandine (rich in iron and aluminum), grossular (rich in calcium), pyrope and spessartine (rich in magnesium or manganese), uvarovite (rich in chromium), and andradite (rich in iron).
Almandine is the hardest and, together with andradite, is the garnet mineral most commonly used in industrial applications. Tsavorite, a rare green grossularite garnet of exceptional beauty is among the most expensive garnets by weight. At the other extreme are reddish pyrope and abundant almandine garnets that are both common and relatively inexpensive.

\section{Where are Garnet Deposits Found in the United States?}

Garnet deposits have been located in 21 different states, including Alaska, Arizona, California, Colorado, Connecticut, Idaho, Montana, Nevada, New Hampshire, New York, North Carolina, Pennsylvania, Utah, and Virginia. However, the only U.S. garnet mines currently active are in northern Idaho, southeastern Montana, and eastern New York. In Idaho, garnet deposits are found adjacent to metamorphic rocks that make up the western Clearwater Range. In Montana, garnet deposits are found in the Ruby Range and southern Tobacco Root Mountains. In both Idaho and Montana, garnets are mined from alluvial deposits that formed from weathering of amphibolite, mica schist, gneiss, or granite. In northeastern New York, garnet is mostly extracted from unweathered gneiss bedrock of the Adirondack Mountains using surface mining methods.

\section{U.S. Industrial Consumption of Garnet}

The United States presently consumes about 16 percent of the global production of industrial garnet. In 2005, domestic production of crude industrial garnet was 40,100 metric tons $(t)$, valued at $\$ 3.84$ million. In the same year, the Nation imported 41,800 t of industrial garnet, valued at $\$ 5.91$ million, primarily coming from Australia, Canada, India, and China.

Meeting the challenge of supplying America's needs for essential minerals such as garnet requires accurate and unbiased scientific data. The ongoing work of scientists with the USGS Mineral Resources Program provides the information crucial to the creation of sound policies that will ensure future supplies of mineral resources.

James G. Evans, Phillip R. Moyle, David G. Frank, and Donald W. Olson

Edited by James W. Hendley II Graphic design by Stephen L. Scott

References

Evans, J.G., 2006, U.S. industrial garnet, in Bliss, J.D., Moyle, P.R., Long K.R., eds., 2002, Contributions to industrial-minerals research: U.S. Geological Survey Bulletin 2209-L [http://pubs.usgs.gov/bul/b2209-I].

Olson, D.W., 2005, Garnet, industrial: U.S. Geological Survey Minerals Yearbook 2005, p. 29.1-29.3 [http://minerals.usgs.gov/ minerals/pubs/commodity/garnet/index. html\#myb].

Hearn, B.C., and McGee, E.S., 1983, Garnets in Montana diatremes; a key to prospecting for kimberlites: U.S. Geological Survey Bulletin 1604, $42 \mathrm{p}$.

U.S. Bureau of Mines, 1995, An overview of production of specific U.S. gemstones [garnet]: U.S. Bureau of Mines Special Publication 14-95 [http://minerals.er.usgs.gov/minerals/pubs/commodity/gemstones/sp14-95/ garnet.html].

\begin{tabular}{|c|}
\hline For more information contact: \\
James G. Evans \\
U.S. Geological Survey \\
904 W. Riverside Ave., Room 202 \\
Spokane, WA 99201 \\
Tel: (509) 368-3115 \\
http://minerals.usgs.gov \\
\\
This Fact Sheet and any updates to it are available online at \\
http://pubs.usgs.gov/fs/2006/3149/
\end{tabular}

